\title{
ANTIOXIDATIVE DEFENSE RESPONSE TO APHID-INDUCED OXIDATIVE STRESS IN Glycine max (L.) Merr. cv. "Nam Dan"
}

\author{
Tran Ngoc Toan', Tran Thi Thanh Huyen ${ }^{2}$, Mai Van Chung1,* \\ ${ }^{1}$ Vinh University, Str. Le Duan 182, Vinh city, Nghe An \\ ${ }^{2}$ Ha Noi University of Education, Str. Xuan Thuy 136, Cau Giay district, Ha Noi \\ *Email: chungmv@vinhuni.edu.vn
}

Received: 25 March 2016; Accepted for publication: 2 June 2016

\begin{abstract}
Infestation of cowpea aphid (Aphis craccivora Koch) induced oxidative stress in leaves of soybean (Glycine max (L.) Merr. cv. "Nam Dan") with a burst in generation of reactive oxygen species (ROS) products such as superoxide anion radical $\left(\mathrm{O}_{2}{ }^{-}\right)$and hydrogen peroxide $\left(\mathrm{H}_{2} \mathrm{O}_{2}\right)$ recorded around 24 hours after aphid feeding. A continuous increase in content of thiobarbituric acid reactive substances (TBARS) in lipid peroxidation and a defined percentage of injury in aphid-infested leaves $(2.20-8.79 \%)$ were resulted from the cellular oxidative damage. An enhanced activity of the antioxidant enzymes such as superoxide dismutase (SOD, EC 1.15.1.1) and catalase (CAT, EC 1.11.1.6) was recorded in leaves of soybean "Nam Dan" from 24 to 48 hours post-infestation (hpi). The enhancement of these enzymes function as the antioxidative response that controlled both ROS-accumulation playing as defensive element and ROSdetoxifying, therefore, reduce the oxidative damage within 48-96 hpi. Activity of SOD and CAT also can improve the tolerance of soybean "Nam Dan" to infestation from A. craccivora.
\end{abstract}

Keywords. soybean "Nam Dan", cowpea aphid, oxidative stress, antioxidative, defense response.

\section{INTRODUCTION}

Oxidative stress, resulting from the strong release of reactive oxygen species (ROS), including superoxide anion radical $\left(\mathrm{O}_{2}^{-}\right)$and hydrogen peroxide $\left(\mathrm{H}_{2} \mathrm{O}_{2}\right)$, is a common phenomenon in plants under effect of the environmental stresses. Being induced by infestation of aphids (Hemiptera: Aphididae), generation of ROS often played both positive and negative impacts to plant cells. The increase of $\mathrm{O}_{2}{ }^{-}$and $\mathrm{H}_{2} \mathrm{O}_{2}$ levels, together with induction of cell death in the infested areas, is an important response in plant defense mechanism against aphid herbivores. Contrary, the high content of ROS can exert toxic effects, and their uncontrolled productions can result in cellular oxidative damage of proteins, lipids, and nucleic acids [1]. To maintain a balance of two those antagonistic roles of ROS, plant cells produce a number of antioxidant enzymes such as superoxide dismutase (SOD), catalase (CAT), peroxidases (POX), etc., which are able to control the ROS-generation as a defensive element and ROS-detoxifying to reduce oxidative damage [2]. However, these antioxidative defense mechanisms are not 
uniformly regulated in plant response to aphids [3]. Within a single plant species, aphid feeding can enhance expression of certain antioxidant enzymes while suppressing others.

Although oxidative responses of plants have been mentioned in several plant-aphid interactions [4,5], no comparable studies were reported for soybean (Glycine max (L.) Merr. cv. "Nam Dan")-a valuable crop in agricultural production in Nghe An province (Vietnam). Furthermore, cowpea aphid (Aphis craccivora Koch), one of the most important pests of leguminous plants, can feed soybean from the germination stage until harvest, therefore, cause serious damages to this crops [6]. In this study, we investigated the antioxidative responses in defense mechanism of G. max cv. "Nam Dan" against infestation of A. craccivora, in which, the changes in levels of $\mathrm{H}_{2} \mathrm{O}_{2}, \mathrm{O}_{2}{ }^{-}$as well as changes in activity of antioxidant enzymes, SOD (EC 1.15.1.1) and CAT (EC 1.11.1.6) were assessed. As an additional objective, the degree of cellular damage was estimated on the basis of electrolyte leakage measurement and levels of thiobarbituric acid reactive substances (TBARS)-product of lipid peroxidation.

\section{MATERIALS AND METHODS}

\subsection{Materials}

\subsubsection{Plant}

Plant used in this study was cultivar "Nam Dan" of soybean (Glycine max (L.) Merr.).

Soybean seeds have been exclusively provided by Nam Dan Agricultural Extension Center (Nghe An province, Vietnam). Seeds were surface-sterilized for 10 minutes in $0.01 \% \mathrm{HgCl}_{2}$ solution and imbibed in the incubator at $22-23{ }^{\circ} \mathrm{C}$ for 48 hours. The germinated seeds were cultured in 20-cm-diameter plastic pots containing Hoagland medium placed in the phytotron with temperature of $23-25{ }^{\circ} \mathrm{C}$, related humidity of $70-75 \%$, light intensity of $110-130 \mu \mathrm{M}$ photons. $\mathrm{m}^{-2} . \mathrm{s}^{-1}$ and light period of 12 light/12 dark hours. Soybean plants in the V3 stage (with first two trifoliate leaves fully developed, third trifoliate leaf unrolled) were used to establish experiments.

\subsubsection{Aphid infestation}

Cowpea aphid (Aphis craccivora Koch) is cultured and supported by Department of Applied Entomology (Institute of Ecology and Biological Resources, Vietnam Academy of Science and Technology, Vietnam).

Each soybean plant in stage V3 was treated by 10 , or 20 , or 30 wingless adults of $A$. craccivora. Aphid individuals were carefully transferred to the estimated leaves with a fine paintbrush. Control was soybean plants without aphid infestation. All control and aphid-infested variants were separately put in clear glass boxes $(50 \mathrm{~cm} \times 50 \mathrm{~cm} \times 50 \mathrm{~cm})$ covered by nylon gauze and placed in the phytotron, in which, the environmental factors such as temperature, relative humidity, light intensity and light period were strictly controlled.

Leaves of soybean plants were collected after 0, 24, 48, 72 and 96 hours post-infestation (hpi) of cowpea aphid. Leaves were carefully taken and weighed, then frozen in nitrogen liquid and kept at $-70{ }^{\circ} \mathrm{C}$ for subsequent analyses. Content of superoxide anion radical $\left(\mathrm{O}_{2}^{-}\right)$and hydrogen peroxide $\left(\mathrm{H}_{2} \mathrm{O}_{2}\right)$ was determined in fresh materials at particular time points. 


\subsection{Analyses}

\subsubsection{Chemicals}

All analytical chemicals were purchased from Singapore supplier of Sigma-Aldrich (USA).

\subsubsection{Determination of superoxide anion radical content}

Determination of superoxide anion radical $\left(\mathrm{O}_{2}{ }^{-}\right)$content in biological samples was based on its ability to reduce nitro blue tetrazolium (NBT) [7]. Soybean leaves $(0.30 \mathrm{~g}$ fresh materialsFW) were immersed in $10 \mathrm{mM}$ potassium phosphate buffer ( $\mathrm{pH} 7.8$ ) containing $0.05 \%$ NBT and $10 \mathrm{mM} \mathrm{NaN}_{3}$ in a final volume of $3 \mathrm{~mL}$ and incubated for an hour at room temperature. After incubation, $2 \mathrm{~mL}$ of the reaction solution was heated at $85{ }^{\circ} \mathrm{C}$ for $15 \mathrm{~min}$ and rapidly cooled. Levels of $\mathrm{O}_{2}{ }^{-}$in soybean leaves were expressed as absorbance at $580 \mathrm{~nm}$ per 1 gram of fresh materials $\left(\mathrm{A}_{580} \cdot \mathrm{g}^{-1} \mathrm{FW}\right)$. The measurement was carried out in the UV-Vis CARY 60 spectrophotometer (Agilent, USA) connected a computer; the spectral data was analyzed by using the UV-Win 5.0 application software.

\subsubsection{Determination of hydrogen peroxide content}

Content of hydrogen peroxide $\left(\mathrm{H}_{2} \mathrm{O}_{2}\right)$ was determined following the spectrophotometric method [8]. Leaves of soybean $(0.50 \mathrm{~g} \mathrm{FW})$ were homogenized with $3 \mathrm{~mL}$ of $5 \%$ trichloroacetic acid (TCA) and $0.10 \mathrm{~g}$ of activated charcoal. The homogenate was centrifuged at $12,000 \times \mathrm{g}$ for $30 \mathrm{~min}$ at $4{ }^{\circ} \mathrm{C}$. The reaction mixture contained extracted solution, $100 \mathrm{mM}$ potassium phosphate buffer $(\mathrm{pH} 8.4)$, and reagent $(0.6 \mathrm{mM} 4-(-2$ pyridylazo)resorcinol : $0.6 \mathrm{mM}$ potassium-titanium oxalate, $1: 1$ in proportion). The decrease of absorbance was measured at a wavelength of 508 $\mathrm{nm}$ in the UV-Vis CARY 60 spectrophotometer. Blanks were obtained by using 5\% TCA to replace extracted solution in the mixture. Content of $\mathrm{H}_{2} \mathrm{O}_{2}$ was determined from the difference of $\mathrm{A}_{508}$ between each sample and blank. The amount of hydrogen peroxide in soybean leaves was expressed as $\mu \mathrm{M} \cdot \mathrm{g}^{-1} \mathrm{FW}$.

\subsubsection{Enzyme assay}

The frozen leaves $(0.50 \mathrm{~g})$ were homogenized at $4{ }^{\circ} \mathrm{C}$ in $2.0 \mathrm{~mL}$ of $50 \mathrm{mM}$ sodium phosphate buffer (pH 7.0), containing $1.0 \mathrm{mM}$ EDTA, $2 \% \mathrm{NaCl}$ and $1 \% \mathrm{PVP}$ (polyvinyl pyrrolidone) and centrifuged at $10,000 \times \mathrm{g}$ for $30 \mathrm{~min}$.

The activity of SOD (EC 1.15.1.1) was spectrophotometrically assayed by measuring its ability to inhibit the photochemical reduction of NBT [9]. The $3 \mathrm{~mL}$ reaction mixture contained $50 \mathrm{mM}$ phosphate buffer ( $\mathrm{pH} 7.8$ ), $13 \mathrm{mM}$ methionine, $75 \mathrm{mM}$ NBT, $0.1 \mathrm{mM}$ EDTA and $30 \mu \mathrm{L}$ of enzyme extract and $2 \mathrm{mM}$ riboflavin. The test tubes were placed $30 \mathrm{~cm}$ below the light of two $15 \mathrm{~W}$ fluorescent lamps and proceeded for $15 \mathrm{~min}$. After that, the measurement was carried out with the UV-Vis CARY 60 spectrophotometer. The amount of the enzyme that caused the inhibition of NBT reduction by $50 \%$ was taken as a unit of SOD activity. The enzyme activity was expressed as nanokatal per $1 \mathrm{mg}$ of protein (nkat.mg ${ }^{-1}$ protein).

The activity of CAT (EC 1.11.1.6) was determined by measuring $\mathrm{H}_{2} \mathrm{O}_{2}$ consumption [10]. The reaction mixture contained $100 \mathrm{mM}$ phosphate buffer $(\mathrm{pH} 7.0), 3 \% \mathrm{H}_{2} \mathrm{O}_{2}$ and plant extract. The reaction was started by introducing $\mathrm{H}_{2} \mathrm{O}_{2}$ to the reaction mixture. The absorbance activity 
was assessed by measuring at $240 \mathrm{~nm}$ against a calibration curve using the UV-Vis CARY 60 spectrophotometer. The activity of CAT was expressed as nkat. $\mathrm{mg}^{-1}$ protein.

\subsubsection{Electrolyte leakage}

Electrolyte leakage was conductometrically measured to assess the injury percentage of plasma membrane [11]. Five fresh leaves of each sample were placed in test-tubes containing 20 $\mathrm{mL}$ of deionized water and incubated on a shaking platform at room temperature for 3 hours. The electrical conductivity of samples was measured with a conductivity meter (Orion Star A320, Thermo Scientific, USA). After the first measurement, leaves were autoclaved at $100{ }^{\circ} \mathrm{C}$ for $20 \mathrm{~min}$ to completely rupture the membranes; the second measurement was done after cooling the solution to room temperature. The membrane damage in aphid-infested leaves was evaluated as the injury percentage compared with control (\%).

\subsubsection{Lipid peroxidation}

Level of lipid peroxidation was determined by thiobarbituric acid reactive substances (TBARS) assay [12]. $0.50 \mathrm{~g}$ of leaves was homogenized in $3 \mathrm{~mL}$ of $0.5 \%$ thiobarbituric acid (TBA) in $20 \%$ trichloroacetic acid (TCA) and centrifuged at $12,000 \times \mathrm{g}$ for $20 \mathrm{~min}$ at $4{ }^{\circ} \mathrm{C}$. A reacted mixture consists of $0.5 \mathrm{~mL}$ of potassium phosphate buffer $(\mathrm{pH} 7.0)$ and $1 \mathrm{~mL}$ of reagent $(0.5 \% \mathrm{TBA}$ in $20 \% \mathrm{TCA}, \mathrm{w} / \mathrm{v})$ and $0.5 \mathrm{~mL}$ aliquot of the supernatant. A blank consisted of 0.5 $\mathrm{mL}$ buffer and $1 \mathrm{~mL}$ reagent. The test-tubes were incubated at $95^{\circ} \mathrm{C}$ for $30 \mathrm{~min}$ and then quickly cooled in an ice bath. After cooling mixes were centrifuged at $10,000 \times \mathrm{g}$ for $10 \mathrm{~min}$ to give a clear supernatant. The absorbance of supernatant was measured at $532 \mathrm{~nm}$ in the UV-Vis CARY 60 spectrophotometer after subtracting the non-specific absorbance at $600 \mathrm{~nm}$. Results are presented as $\mu \mathrm{M}$ TBARS. $\mathrm{g}^{-1} \mathrm{FW}$.

\subsection{Statistical analysis}

All analyses were performed in three replicates in three independent experiments. Analysis of variance (ANOVA) was applied to verify whether means from the given experimental variants were significantly different with the level of significance as $\mathrm{P}$-value $<0.05$. Data shown in the figures are means of triplicates for each variant and standard errors (s.e.).

\section{RESULTS AND DISCUSSION}

\subsection{Aphid-accumulated reactive oxygen species}

An accumulation of reactive oxygen species (ROS) such as superoxide anion radical $\left(\mathrm{O}_{2}{ }^{-}\right)$ and hydrogen peroxide $\left(\mathrm{H}_{2} \mathrm{O}_{2}\right)$ in leaves of soybean (G. max cv. "Nam Dan") was revealed to induce by infestation of cowpea aphid (A. craccivora Koch).

A strong generation of $\mathrm{O}_{2}^{-}$was observed from 0-24 hpi in soybean leaves infested by 20 and 30 aphids, whereas infestation of 10 aphids caused an increased content of $\mathrm{O}_{2}{ }^{-}$within 0-48 hpi. The highest amount of $\mathrm{O}_{2}^{-}$obtained at 24 hpi in leaves infested by 30 aphids was 8.73 $\mathrm{A}_{580} \mathrm{~g}^{-1} \mathrm{FW}$, having by 3.68- and 3.94-fold higher than in control and in the beginning, respectively. The most remarkable differences between $\mathrm{O}_{2}{ }^{--}$content in the aphid-treated and in control plants were recorded within 24-48 hpi, however, levels of that free radical in the infested leaves were not significantly different from that observed in control within 72-96 hpi (Fig. 1a). 
A limited available studies regarding the involvement of $\mathrm{O}_{2}{ }^{-}$in plant defense against insect herbivores documented that, $\mathrm{O}_{2}^{--}$played as a feeding deterrent against the infestation of aphid [8], or converted into $\mathrm{H}_{2} \mathrm{O}_{2}$ via catalyzing by enzyme superoxide dismutase (SOD), and then $\mathrm{H}_{2} \mathrm{O}_{2}$ functions as a signal molecule to initiate responses [13]. A large amount of $\mathrm{O}_{2}{ }^{-}$in the cell wall also contributed to limit the invasion of viral pathogens that can be directly transmitted from aphid saliva during its penetration into plant tissues [6].

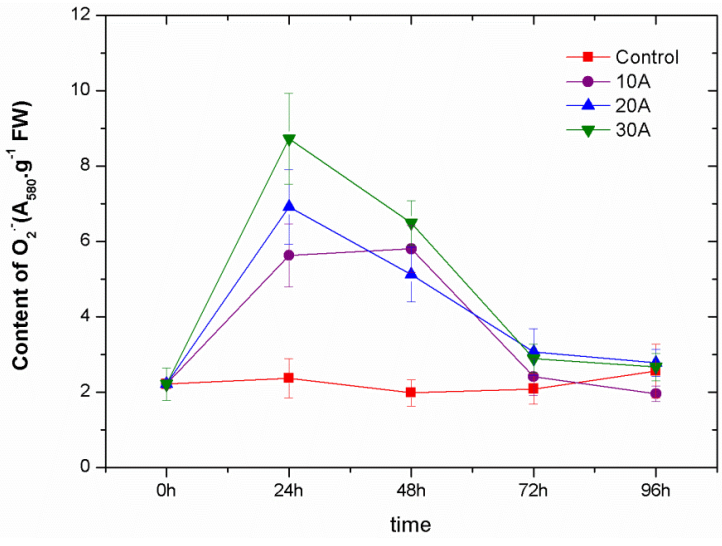

a

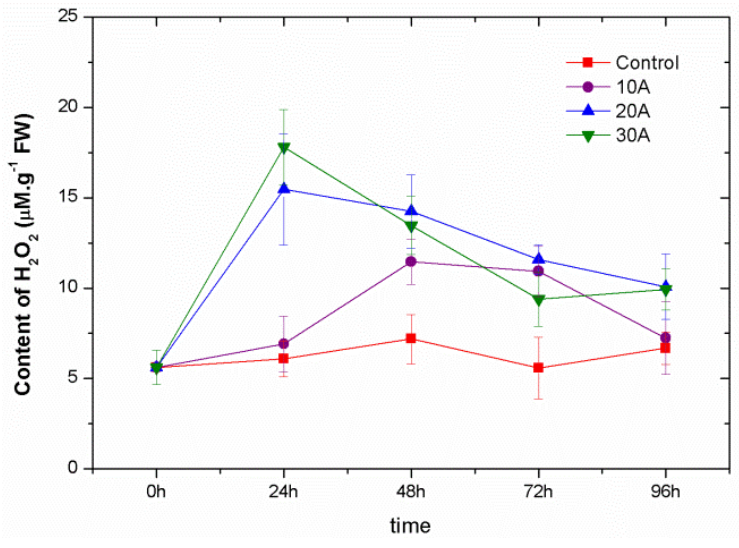

b

Figure 1. Content of $\mathrm{O}_{2}{ }^{--}$(a) and $\mathrm{H}_{2} \mathrm{O}_{2}$ (b) in leaves of G. max cv. "Nam Dan" control and A. craccivora infested plants.

In soybean leaves, $\mathrm{H}_{2} \mathrm{O}_{2}$ showed a remarkable accumulation to the highest content at 24 hours after infestation of 20 or 30 aphids, having 2.54-, and 2.92-fold higher than at the beginning, respectively. This ROS molecule then continuously decreased to lower levels within 48-96 hpi. In control, $\mathrm{H}_{2} \mathrm{O}_{2}$ remained at low levels throughout experiment (Fig. 1b). ANOVA results showed that the differences in content of $\mathrm{H}_{2} \mathrm{O}_{2}$ in 20 and 30 aphid-infested variants and control in all estimated time were highly significant; whereas, that in 10 aphid-infested leaves obtained within 48-72 hpi $(\mathrm{P}<0.05)$.

$\mathrm{H}_{2} \mathrm{O}_{2}$ is a relatively stable partially-reduced form of ROS and its ability to diffuse freely allows $\mathrm{H}_{2} \mathrm{O}_{2}$ to play a control role in the generation of the defense response in plants $[13,14]$. An early accumulation of $\mathrm{H}_{2} \mathrm{O}_{2}$ to high levels in soybean "Nam Dan" at 24 hpi could be the beginning of a cascade of events that triggers physiological and molecular responses to prevent or minimize cowpea aphid attack.

\subsection{Cellular membrane damage}

The burst of $\mathrm{O}_{2}{ }^{-}$and $\mathrm{H}_{2} \mathrm{O}_{2}$ generation often causes "oxidative damage" in living cell. The induction of damaged cellular components often associates to leakage of cellular content and lipid peroxidation, and leads to cell death in herbivore-effected areas. 


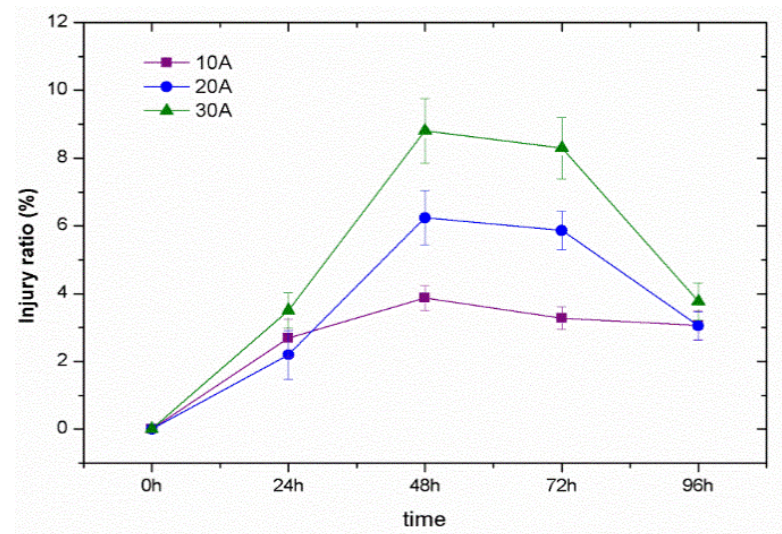

Figure 2. The percentage of injury (based on electrolyte leakage) in leaves of G. max cv. "Nam Dan" infested by A. craccivora compared with control plants.

The percentage of injury (based on electrolyte leakage) in soybean "Nam Dan" leaves' cells caused by A. craccivora infestation compared with control is shown in Figure 2. An increase in the electrolyte leakage in all aphid-infested leaves from 0 to 48 hpi was followed by a decrease within 72-96 hpi. The highest percentages of injury were recorded at $48 \mathrm{hpi}$, having by $3.87 \%$, $6.24 \%$, and $8.79 \%$ (in proportion to infestation of 10, 20 and 30 aphids, respectively) higher than in control plants. ANOVA showed the significant differences between the injury ratio in 20 and 30 aphid-treated variants compared with control within 48-72 hpi $(\mathrm{P}<0.05)$.

Increased electrolyte leakage is used to monitor loss of membrane integrity, and hence can indicate damage in leaf cells caused by feeding activities. The maximum injury percentage in soybean leaves after cowpea aphid infestation was only $8.79 \%$. Therefore, it can be assumed that the components of aphid sheath and watery saliva can play a pivotal role in establishing physical and chemical constraints on electrolyte leakage. A. craccivora has probably developed a range of physical and chemical properties to minimize wounding area and to limit electrolyte leakage, therefore, reduce plant response to stylet penetration.

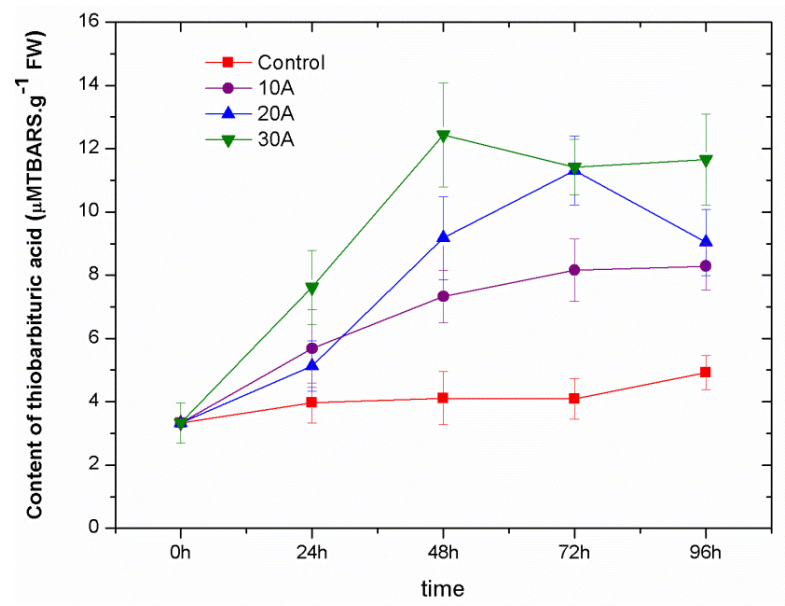

Figure 3. Lipid peroxidation in leaf tissues of G. $\max \mathrm{cv}$. "Nam Dan" control and A. craccivora infested plants.

A well-established mechanism of cellular injury in plants and is used as an indicator of oxidative stress is lipid peroxidation that was measured as the amount of thiobarbituric acid 
reactive substances (TBARS). A progressive increase in content of TBARS was recorded in leaves of G. max cv. "Nam Dan" in the duration of A. craccivora infestation and reached to various maximum levels under the influence of different numbers of cowpea aphid (Fig. 3). The

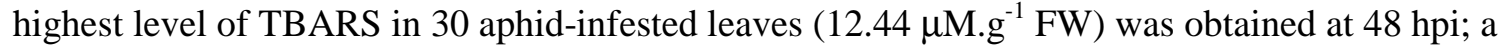

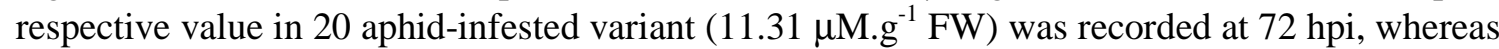
that in 10 aphid-infested soybean was continuously increased till 96 hpi. However, in all analyzed point time, TBARS content in aphid-infested leaves was significant higher than in control $(\mathrm{P}<0.05)$.

Results of our study in soybean "Nam Dan" were in agreement with previous reports, which all confirmed that the increase in lipid peroxidation in crops, e.g., pea plants, was directly induced by aphids' feeding [6]. Therefore, we can conclude that, infestation of A. craccivora stimulated a strong generation of $\mathrm{O}_{2}{ }^{-}$and $\mathrm{H}_{2} \mathrm{O}_{2}$ in leaves' cells of $G$. max cv. "Nam Dan", which caused oxidative damage of membrane integrity due to the increase in percentage injury of cell membrane and activation of lipid peroxidation processes.

\subsection{Activity of antioxidant enzymes}

The spectrophotometric analyses showed an enhancement of enzyme SOD in G. max cv. "Nam Dan" infested by A. craccivora. Activity of this enzyme in aphid-infested leaves increased in most of estimated time points, and was much higher than in control (Fig. 4a). In the case of soybean plants infested by 30 aphids, activity of SOD increased remarkably and reached the highest value at $48 \mathrm{hpi}$ (31.49 nkat.mg ${ }^{-1}$ protein), having by $197.12 \%$ and $266.86 \%$ higher than that observed in control and at the beginning, respectively. In turn, SOD activity in leaves infested by 10 and 20 aphids increased up to $72 \mathrm{hpi}$ and was higher than in 30 aphid-infested leaves within 72-96 hpi. ANOVA analyses showed significant differences between the SOD activities in all aphid-infested leaves and control from 48 to 96 hpi $(\mathrm{P}<0.05)$.

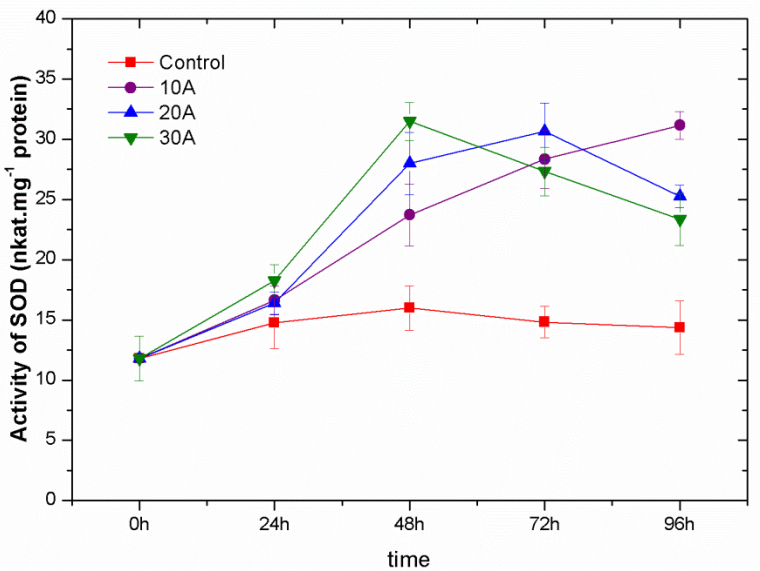

a

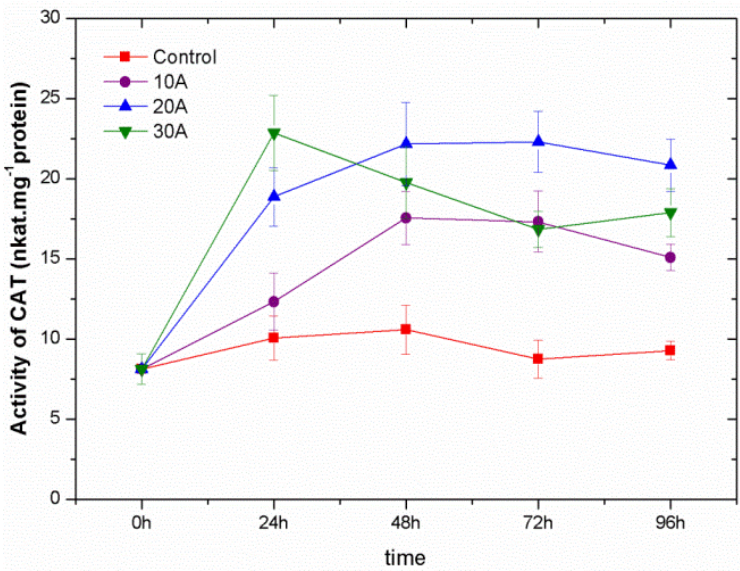

$\mathrm{b}$

Figure 4. Activity of SOD (a) and CAT (b) in leaves of G. $\max$ cv. "Nam Dan" control and A. craccivora infested plants.

Within the living cells, SOD constitutes the first line of defense against ROS, because this enzyme can counteract oxidative damage caused by over-accumulation of superoxide anion radical. As enzyme engaged in the dismutation of $\mathrm{O}_{2}^{--}$, the remarkably increased activity of SOD in the aphid-infested leaves of soybean "Nam Dan" caused for a strong decrease in level of $\mathrm{O}_{2}{ }^{-}$ 
in the period time of 48-96 hours (Fig. 1a). It was suggested that an enhancement of SOD activity was directly involved the resistance of soybean "Nam Dan" to cowpea aphid.

Similar to SOD, activity of CAT in soybean leaves was also induced by A. craccivora infestation. The large contents of CAT in aphid-infested leaves were noted at $24 \mathrm{hpi}$ and maintained in high levels until ending of experiment (Fig. 4b). ANOVA analyses revealed a significant difference between activities of CAT in aphid-infested leaves and control during the experimental time $(\mathrm{P}<0.05)$.

Our study supported that CAT may contribute to the defense mechanisms of G. max cv. "Nam Dan" against A. craccivora infestation by regulating levels of $\mathrm{H}_{2} \mathrm{O}_{2}$. The activation of CAT was disproportionately higher than $\mathrm{H}_{2} \mathrm{O}_{2}$ generation in soybean leaves. High activity of CAT within 24-96 hpi strongly catalyzes $\mathrm{H}_{2} \mathrm{O}_{2}$ breakdown into $\mathrm{H}_{2} \mathrm{O}$ and $\mathrm{O}_{2}$, therefore, reduced level of this ROS product, and the relatively low accumulation of $\mathrm{H}_{2} \mathrm{O}_{2}$ from 48 to 96 hpi was probably due to the high activation of CAT (Fig. 1b). A strong enhancement of CAT protects soybean leaf cells against an excess of $\mathrm{H}_{2} \mathrm{O}_{2}$ and thus against considerable membrane damage.

The high efficiency of the antioxidative enzymes such as SOD and CAT observed in soybean "Nam Dan" is one of the most important elements of the defense mechanisms to oxidative stress. SOD and CAT regulated to generate $\mathrm{O}_{2}{ }^{-}$and $\mathrm{H}_{2} \mathrm{O}_{2}$ to function as defensive element but detoxify the excess of ROS to reduce oxidative damage. In addition, the enhanced activity of SOD and CAT in soybean leaves under A. craccivora attack also plays an important role in the stress tolerance of G. $\max \mathrm{cv}$. "Nam Dan".

\section{CONCLUSION}

Cowpea aphid infestation induced the oxidative stress in leaves of soybean (Glycine max (L.) Merr. cv. "Nam Dan") with a burst of $\mathrm{O}_{2}{ }^{-}$and $\mathrm{H}_{2} \mathrm{O}_{2}$ released in 24 hours after aphid attack. The cellular damage resulted from oxidative stress were obviously confirmed by a continuous increase in content of TBARS, product of membrane lipid peroxidation, and a defined percentage of injury $(2.20-8.79 \%)$ in soybean leaves' cells. The accumulation in activity of antioxidant enzymes SOD and CAT since 24 hours following cowpea aphid infestation played as the antioxidative defense response of soybean "Nam Dan" via the mode, in which, these enzymes catalyzed to reduce content of $\mathrm{O}_{2}{ }^{-}$and $\mathrm{H}_{2} \mathrm{O}_{2}$, therefore, contributing to control oxidative stress in soybean leaves.

Acknowledgement. This research is funded by Vietnam National Foundation for Science and Technology Development (NAFOSTED) under grant number: 106-NN.03-2014.22.

\section{REFERENCES}

1. Radville L., Chaves A., and Preisser E. L. - Variation in plant defense against invasive herbivores: evidence for a hypersensitive response in Eastern Hemlocks (Tsuga canadensis). J. Chem. Ecol. 37 (2011) 592-597.

2. Ahmad P., Sarwat M., and Sharma S. - Reactive oxygen species, antioxidants and signaling in plants. J. Plant Biol. 51 (2008) 167-173. 
3. Divol F., Vilaine F., Thibivilliers S., Amselem J., Palauqui J.C., Kusiak C., and Dinant S. - Systemic response to aphid infestation by Myzus persicae in the phloem of Apium graveolens. Plant Mol. Biol. 57 (2005) 517-540.

4. Mai V. C., Bednarski W., Borowiak-Sobkowiak B., Wilkaniec B., Samardakiewicz S., and Morkunas I. - Oxidative stress in pea seedling leaves in response to Acyrthosiphon pisum infestation. Phytochemistry 93 (2013) 49-62.

5. Moloi M. J., and van der Westhuizen A. J. - Antioxidative enzymes and the Russian wheat aphid (Diuraphis noxia) resistance response in wheat (Triticum aestivum). Plant Biol. 10 (2008) 403-407.

6. Capinera J. L. - Handbook of Vegetable pests. Academic Press, New York, 2001, pp. 575

7. Doke N. - Involvement of superoxide anion generation in the hypersensitive response of potato tuber tissues to infection with an incompatible race of Phytophthora infestans and to the hyphal wall components. Physiol. Plant Pathol. 23 (1983) 345-357.

8. Becana M., Aparicio-Tejo P., Irigoyen J.J., and Sanchez-Diaz M. - Some enzymes of hydrogen peroxide metabolism in leaves and root nodules of Medicago sativa. Plant Physiol. 82 (1986) 1169-1171.

9. Beauchamp C., and Fridovich I. - Superoxide dismutase: improved assays and an assay applicable to acrylamide gels. Anal. Biochem. 44 (1971) 276-287.

10. Dhindsa R.S., Plumb-Dhindsa P., and Thorpe T.A. - Leaf senescence: correlated with increased levels of membrane permeability and lipid peroxidation, and decrease levels of superoxide dismutase and catalase. J. Exp. Bot. 32 (1981) 93-101.

11. Sullivan Y.C. - Techniques of measuring plant drought stress. In: Larson K.L., and Eastin J.D. (Eds.) - Drought injury and resistance in crops. Crop Science Society of America, Madison, WI, 1971, pp. 1-8.

12. Heath R. L., and Packer L. - Photoperoxidation in isolated chloroplasts. I. Kinetics and stoichiometry of fatty acid peroxidation. Arch. Biochem. Biophys. 125 (1968) 189-198.

13. Orozco-Cárdenas M., and Ryan C.A. - Hydrogen peroxide is generated systemically in plant leaves by wounding and systemin via the octadecanoid pathway. Proc. Natl. Acad. Sci. USA 96 (1999) 6553-6557.

14. Bóka K., Orbán N., and Kristóf Z. - Dynamics and localization of $\mathrm{H}_{2} \mathrm{O}_{2}$ production in elicited plant cells. Protoplasma 230 (2007) 89-97.

\title{
TÓM TẮT
}

\section{PHẢN ỨNG BẢO VÊ CỦA GIỐNG ĐẨU TƯƠNG NAM ĐÀN ĐỐI VỚI STRESS "ÔXY HÓA" GÂY RA BỞI RẸP MUỘI ĐEN}

\author{
Trần Ngọc Toàn ${ }^{1}$, Trần Thị Thanh Huyền ${ }^{2}$, Mai Văn Chung ${ }^{1, *}$ \\ ${ }^{1}$ Trường Đại học Vinh, 182 Lê Duẩn, thành phố Vinh, tỉnh Nghệ An \\ ${ }^{2}$ Truò̀ng Đại học su phạm Hà Nội, 136 Xuân Thủy, Cầu Giáy, thành phố Hà Nội \\ *Email: chungmv@vinhuni.edu.vn
}


Tác động của rệp muội đen (Aphis craccivora Koch) đã cảm ứng stress "ôxy hóa" ở lá cây đậu tương Nam Đàn (Glycine max (L.) Merr.) với sự bùng nổ sinh tổng hợp các dạng ôxy hoạt hóa như gốc tự do superoxide $\left(\mathrm{O}_{2}{ }^{-}\right)$và hydrogen peroxide $\left(\mathrm{H}_{2} \mathrm{O}_{2}\right)$ sau 24 giờ gây hại. Stress "ôxy hóa" đã gia tăng liên tục quá trình peroxide hóa lipid, làm thay đồi cấu trúc, chức năng của màng sinh chất, gây thiệt hại ở các tế bào lá đậu tương Nam Đàn với tỉ lệ tổn thương 2,20 - 8,79\%. Trong những lá bị stress đã có sự cảm ứng tăng cường hoạt độ các enzyme chống ôxy hóa như superoxide dismutase (SOD, EC 1.15.1.1) and catalase (CAT, EC 1.11.1.6) sau khi rệp phá hại 24 - 48 giờ. Các enzyme này kiểm soát sinh tổng hợp $\mathrm{O}_{2}{ }^{--}$và $\mathrm{H}_{2} \mathrm{O}_{2}$, góp phần giảm thiểu thiệt hại do stress "ôxy hóa" trong 48 - 96 giờ, đồng thời duy trì lượng ôxy hoạt hóa cần thiết để tham gia các phản ứng bảo vệ, tăng cường khả năng chống chịu của đậu tương Nam Đàn đối với sự phá hại của rệp.

Tù khóa: đậu tương Nam Đàn, rệp muội đen, stress “ôxy hóa”, enzyme chống ôxy hóa. 